\title{
Technè
}

La science au service de l'histoire de l'art et de la préservation des biens culturels

43 | 2016

Une Europe de la recherche en sciences du patrimoine

\section{An ARCHLAB project: researches on the painting technique of the three panels of the Battle of San Romano by Paolo Uccello}

Un projet d'ARCHLAB. Recherches sur la technique picturale des trois panneaux de La Bataille de San Romano de Paolo Uccello

\section{Muriel Vervat}

\section{(2) OpenEdition}

\section{Journals}

Electronic version

URL: http://journals.openedition.org/techne/839

DOI: $10.4000 /$ techne.839

ISSN: 2534-5168

\section{Publisher}

C2RMF

\section{Printed version}

Date of publication: 1 August 2016

Number of pages: $110-113$

ISBN: 978-2-7118-6338-9

ISSN: $1254-7867$

\section{Electronic reference}

Muriel Vervat, « An ARCHLAB project: researches on the painting technique of the three panels of the Battle of San Romano by Paolo Uccello », Technè [Online], 43 | 2016, Online since 19 December 2019, connection on 24 July 2020. URL : http://journals.openedition.org/techne/839 ; DOI : https://doi.org/ 10.4000/techne.839

\section{(c) (†) $९$}

La revue Technè. La science au service de l'histoire de l'art et de la préservation des biens culturels est mise à disposition selon les termes de la Licence Creative Commons Attribution - Pas d'Utilisation Commerciale - Pas de Modification 4.0 International. 


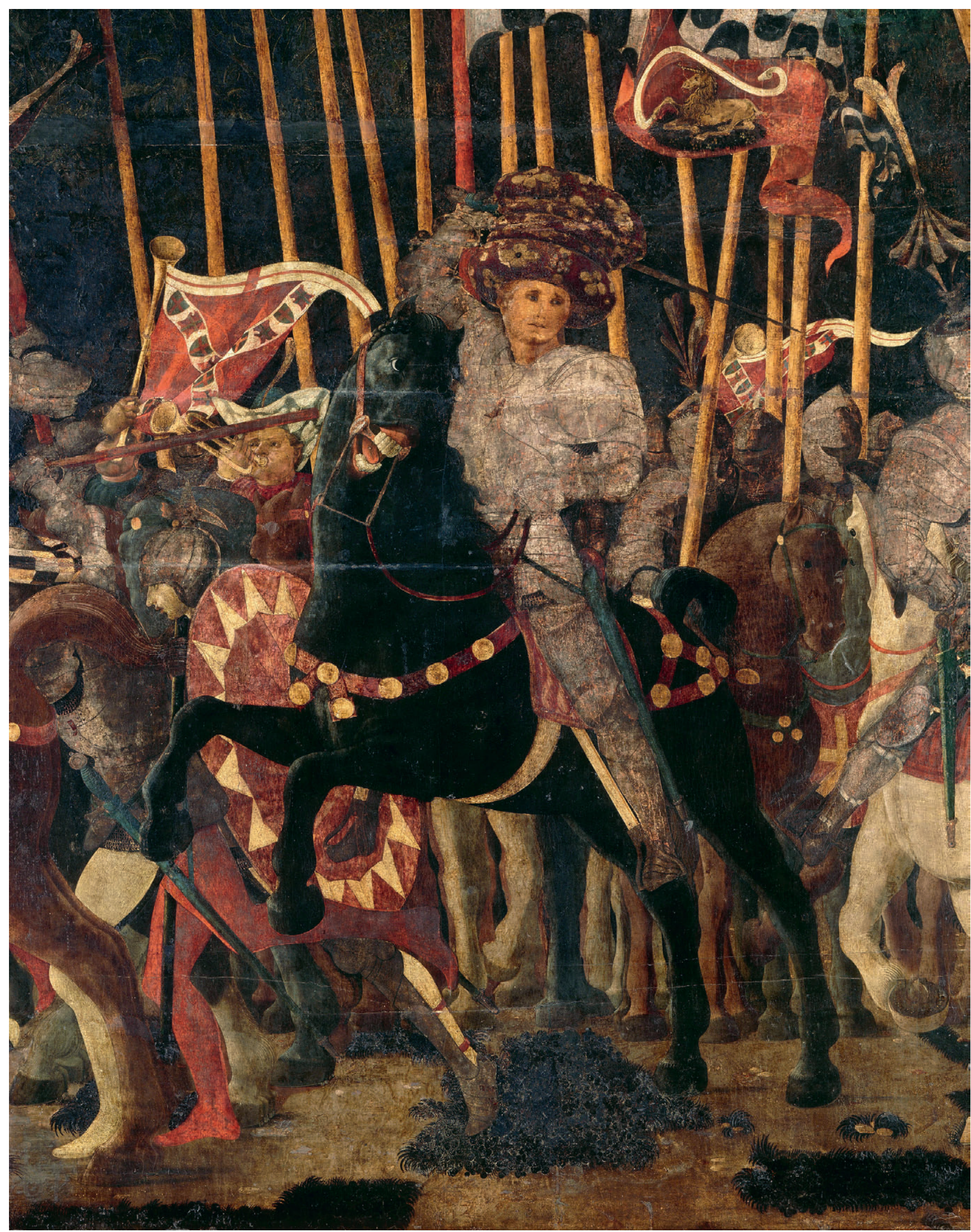

Fig. 1. Paolo Uccello, Battle of San Romano, musée du Louvre, Paris.

(c) RMN-Grand Palais (musée du Louvre)/Daniel Arnaudet. 
Muriel Vervat

\section{An ARCHLAB project: researches on the painting technique of the three panels of the Battle of San Romano by Paolo Uccello}

Un projet d'ARCHLAB. Recherches sur

la technique picturale des trois panneaux de La Bataille de San Romano de Paolo Uccello

\begin{abstract}
The objective of this research was to create a comparative database comprising findings from the London and Paris Battle's with those that are currently being obtained from the research on the Uffizi painting. With experts from the Scientific Departments of the two Museums we made a comparative study of the silver-leaf usage and decoration techniques, and study the nature of the decorative organic layers present on the surface of metal leaf, from the perspective of technical art history and as a possible tool for cleaning options of the Uffizi panel.

Keywords. Scientific archives intercomparison, X-ray radiography, UV fluorescence, IR reflectography, IR false colour photography, X-ray fluorescence analysis (XRF) Diagnostic imaging techniques with high resolution digital photography, visible raking light photography, fibre optic reflectance spectroscopy (FORS).
\end{abstract}

Résumé. Cette recherche avait pour objectif d'élaborer une base de données comparatives sur les panneaux de La Bataille de San Romano conservés au Louvre, à la National Gallery et à la galerie des Offices, où l'œuvre est en cours d'examen. Avec des spécialistes des laboratoires du Louvre et de la National Gallery, nous avons effectué une étude comparée de l'utilisation de la feuille d'argent et des techniques de décoration. Nous avons analysé la nature des couches organiques présentes à la surface de la feuille métallique, à la fois du point de vue de l'histoire technique de l'art et afin de guider éventuellement le choix des procédés de nettoyage pour le panneau des Offices.

Mots-clés. Intercomparaison d'archives scientifiques, radiographie X, fluorescence d'ultraviolets, réflectographie en infrarouge (RIR), photographie infrarouge en fausse couleur, fluorescence des rayons $X$ (FRX), imagerie diagnostique par photographie numérique à haute résolution, photographie en lumière visible rasante, spectroscopie de réflexion à fibre optique (SRFO).
One of the most important profane cycles of the Florentine Renaissance is the one Paolo Uccello painted from the early 1440 s on three wide panels, depicting three moments of the Battle won by the Florentine army. Today, because of the dispersion that occurred in the 19th century, these paintings adorn three of the most important European museums, the Louvre in Paris (Micheletto da Cotignola in Battle), the National Gallery in London (Niccolò Mauruzi da Tolentino at the Battle of San Romano) and the Uffizi in Florence (the Battle of San Romano $)^{1}$.

In 2009, the administration of the Uffizi Gallery decided to undertake a diagnostic assessment and survey in view of future treatments for the Battle of San Romano.

The restoration reports at the archives of the Uffizi Gallery confirm that, in 1954, the conservator L. Tintori undertook a series of treatments on the aforementioned panel painting. The intervention included the removal of the oxidized/aged varnish and in-paintings, which appeared altered in colour, addition of new fillings, colour loss retouching, and applying pigmented glazes over abraded areas. Only a few analyses were performed at that time to identify the materials used by the artist and the causes which produced their alterations.

The present study, funded through an ARCHLAB grant, intended to set up a comparative database dealing with the conservation and scientific technical reports of the London and Paris panels as well as the study performed on the Florentine painting. The aim of this project was to establish whether the actual causes of deterioration/alteration of the Uffizi panel were mainly the result of previous conservation interventions, or of other environmental factors. For example, in the Battle of San Romano at the Uffizi, the type of craquelure and the fact that the paint layers showed a different behaviour in ageing could be due to the presence (or, in some cases, to the absence) of an underlying canvas layer. Although a technical report on the London panel was published in 2000 by Ashok Roy and Dillian Gordon ${ }^{2}$, other unpublished data are present in the archives of the National Gallery Scientific Department and at the C2RMF. The visits to these scientific Laboratories within the CHARISMA project made it possible

Muriel Vervat, Paintings Conservator granted by the Italian State Ministero per i Beni Culturali Opificio delle Pietre Dure in Florence, Private Practice, currently working for the Uffizi Museum. (murielvervat@libero.it). 
to study the technical documentation of the three paintings, particularly the X-radiography, and to compare the structures of the three supports, their preparations, all the existing cross-sections and the results of the analysis of the pigments and organic binding media.

\section{The diagnostic project on the Uffizi panel}

In order to establish the best possible methodology for defining the conservation treatment, the diagnostic project was defined in collaboration with A. Aldrovandi, physicist at the Scientific Laboratory of the OPD. Diagnostics and examinations were performed by laboratories from Universities and Italian public Institutions.

For evident reasons, using portable in situ non-invasive techniques of investigation were preferred: X-ray radiography (already recorded in 1992 by M. Seracini, during the restoration of the wood panels), UV fluorescence, IR reflectography, IR false colour by A. Aldrovandi and S. Cipriani (OPD), X-ray fluorescence analysis (XRF) by P. Moioli and C. Seccaroni (ENEA), Diagnostic imaging techniques with high resolution digital photography, visible raking light macro-photography by S. Bracci (ICVBCCNR), Fiber optic reflectance spectroscopy (FORS) by M. Picollo (IFAC-CNR).

In addition, in terms of laboratory invasive techniques, the following were carried out: Cross-sections by M. Favaro (ICIS-CNR), S. Bracci (ICVBC-CNR) and FT-IR and GC-MS by M. P. Colombini (Pisa University).

As in the case of the related paintings in London and Paris, also on the Battle in Florence, the upper corners have additions which convert the original shape of the support to a rectangle. In the 19th century, the thickness of the Florentine poplar panel was reduced from the original thickness of about $4 \mathrm{~cm}$, to $1.2-1.3 \mathrm{~cm}$. All three panel paintings show evident signs of a drastic over cleaning.

\section{Some examples of painting technique of the three panels of the Battle of San Romano}

\section{Metal leaf}

The cross-sections taken from the armour of the horse-men, showed the presence on top of the preparatory layer of gesso in animal glue, a layer of bole of an orange-brown tonality, on which the metal leaf had been applied. The same investigation carried out at the National Gallery Scientific Department and C2RMF on the other two panels by Uccello, confirmed the presence of the same layer structure. In all instances, the thickness of the silver leaf was not in excess of 5 microns (fig. 2).

Similarly, on all three panels, a complex painting sequence was found on top of the metal leaf, executed with carbon black, with which the artist with the care of a miniaturist, has depicted the individual pieces of the cuirasses. The soft edges of the shadows are achieved with the use of the thumb, pressed into the paint while still wet so as to blur the marks of the brush on the metal surface. The use of fingers to attenuate the marks of the brush was common practice among painters at the time, and many examples as evidence of the practice; nevertheless, the emotion is strong when one finds traces of the artist's hand beneath the grime (fig. 3).

The silver leaf has been used as a base for opaque layers of paint: on the head covering (marzocco), on top of the silver, one finds lapis lazuli alternating with azurite, which thus suggests the presence of different textiles, such as velvet and silk. On the helmets of the group of horsemen on the right who are pursuing the enemy, the artist has covered the silver leaf with vermilion and lake which he has subsequently scratched through (sgraffito), modelling thus the outlines of the various plumes.

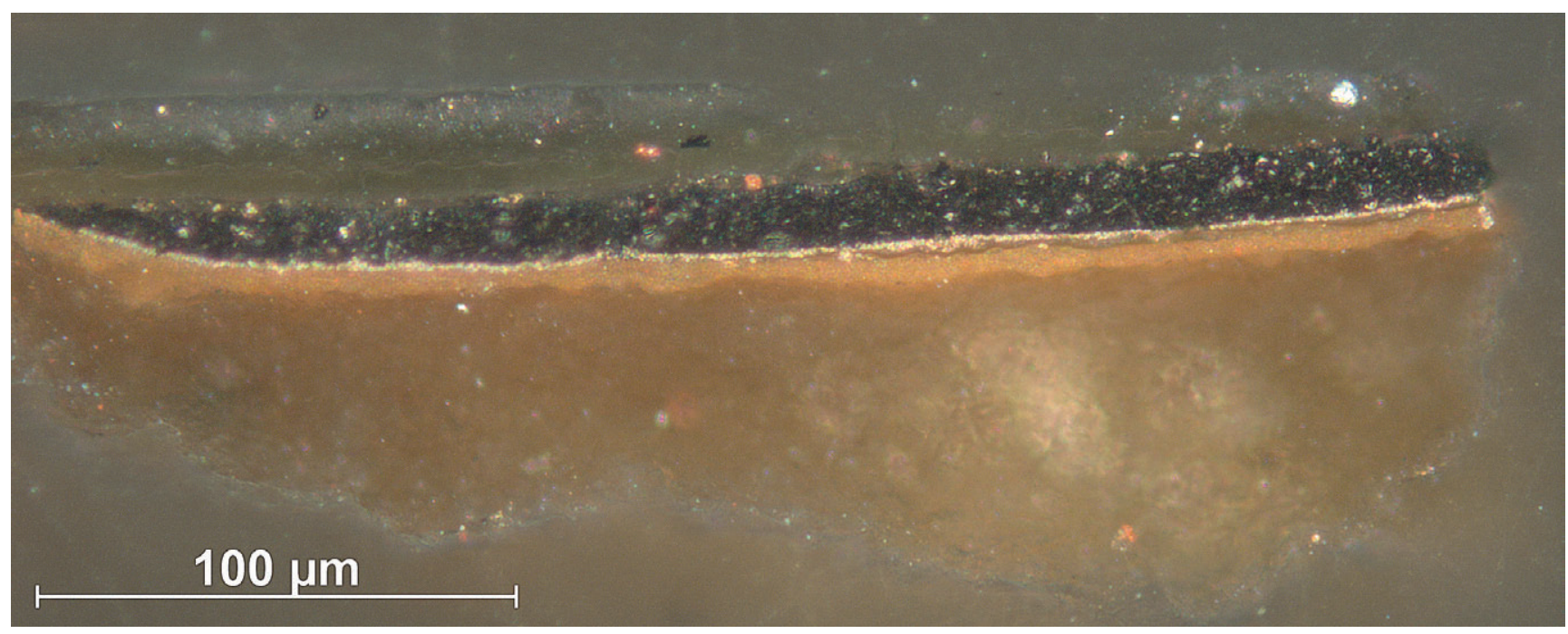

Fig. 2. NG 583_S55_XS_VIS_50xB-Cross section showing a thin layer of silver leaf for armour, with orange-brown bole beneath. A black glaze is present at the surface. ( ) With permission of Ashok Roy, Scientific department, National Gallery. 


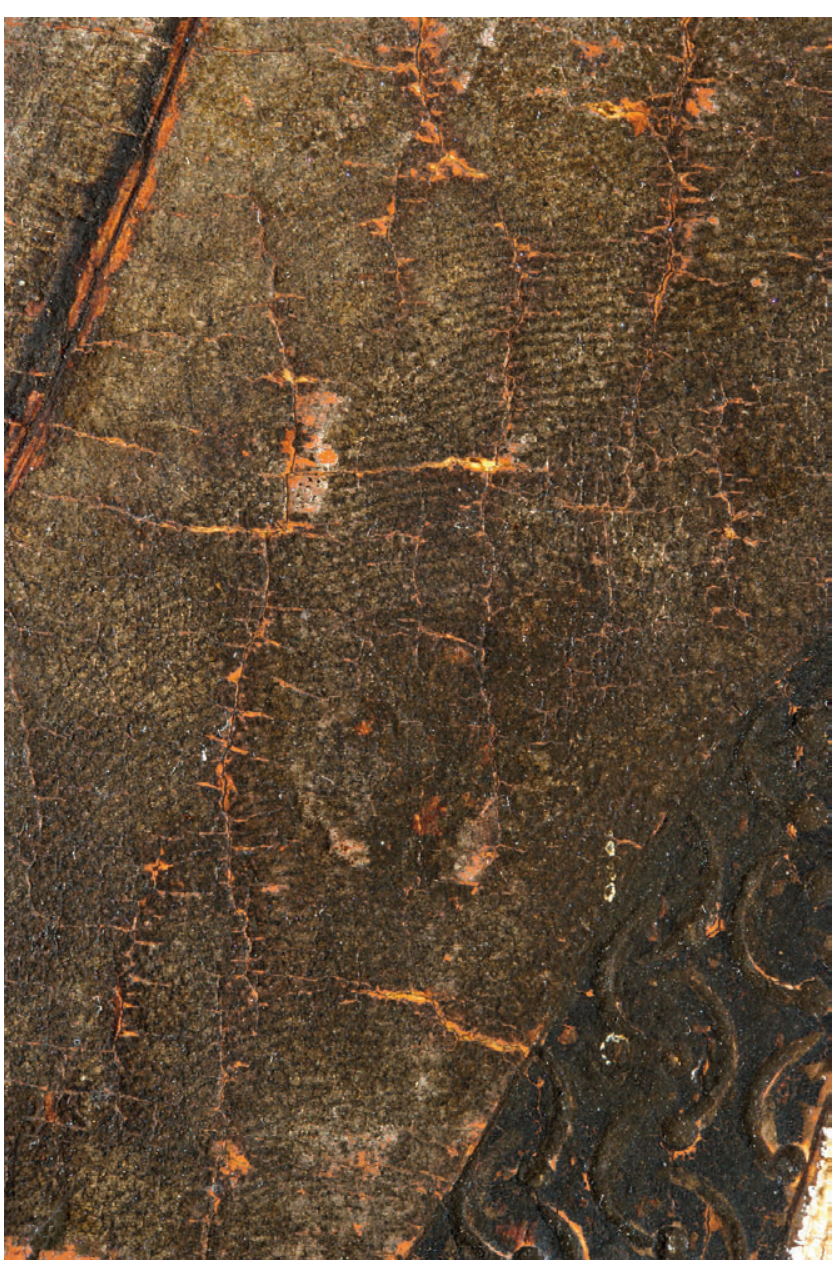

Fig. 3. Detail of the silver leaf armour of a knight, over the red horse on the left, showing fingerprints in the brownish black surface glaze. (c) Uffizi Gallery, Florence/Antonio Quattrone.

\section{Incisions and the use of three-dimensional models}

Among the characteristics of the painting technique of Paolo Uccello, evidence is found in all three panels of the use of incisions carried out with a sharp point, whether as a first sketch for the drawing, or to delimitate the areas to which either silver or gold leaf would be applied. As is also reported by Cennino Cennini in his Libro dell'Arte (beginning of the 15 th century), the painter would incise into the gesso the outlines of the painted sections adjacent to areas of gilding, so as to furnish clear indications to the gilder. In the Battles, the incisions are liberally employed also to mark out particularly 'delicate' elements, such as the raised hoof of a horse, or the outline of the figure of an halberdier (fig. 4).

In the Uffizi painting, in order to construct his battle-field filled with horses in action (there are at least twenty of them, seen frontally, fore-shortened or fallen, from the side or in flight), it seems likely that the painter made use in some cases of small three-dimensional models. This hypothesis is based on the identical position (but depicted from different angles) of the legs of the ochre-coloured horse - on the extreme left of the painting - who is raised on his back legs, with his forelegs beating the air, and those seen in foreshortening belonging to the dying dark grey horse whose muzzle grazes the front right edge of the painting, as well as those of the white horse seen in profile in the centre.

Although the panels were painted over a span of years (1438-1440), all three present similarities both in their conception and realisation, which give the impression of a single project, which the artist followed in person. So it is of fundamental importance not to study an art piece in isolation from its context, particularly in this case, where the painting forms a part of a set of three paintings created together and that have shared a similar conservation history until the end of the 18 th century.

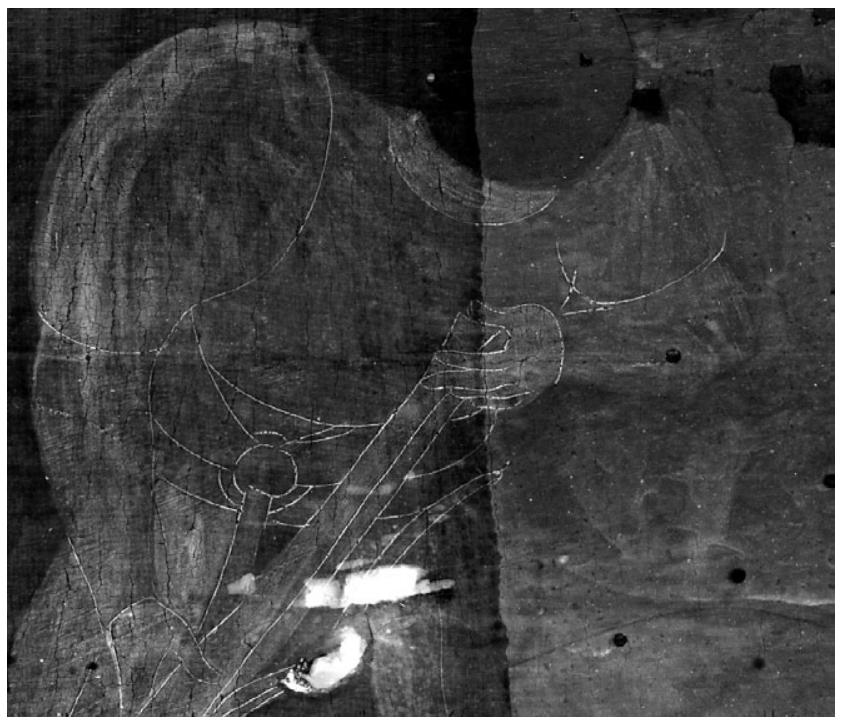

Fig. 4. X-ray detail of a halberdier with incised lines around all the figure. () Uffizi Gallery, Florence/Editech/Maurizio Seracini.

Notes

1. F. Borsi, S. Borsi, Paolo Uccello, Milano, 1992, p. 126-128; P. Roccasecca, Paolo Uccello, le battaglie, Milano 2007, Caglioti. Nouveautés sur la Bataille de San Romano de Paolo Uccello, Revue du Louvre et des Musées de France, LI,4, 2001, p. 37-54.

2. Roy, A., Gordon, D., "Uccello's Battle of San Romano", National Gallery Technical Bulletin Vol. 22, 2001, p. 4-17.

(http://www.nationalgallery.org.uk/ uccellos-battle-of-san-romano) 